\title{
Biogenic amines in the meat of hunted pheasant and hare during the course of storage
}

\author{
Zdeňka Hutařová, Vladimír Večerek, Petr Maršálek \\ University of Veterinary and Pharmaceutical Sciences, \\ Faculty of Veterinary Hygiene and Technology, \\ Department of Veterinary Public Health and Animal Welfare, \\ Brno, Czech Republic \\ Received April 23, 2014 \\ Accepted October 22, 2014
}

\begin{abstract}
Venison is becoming more and more interesting for consumers. Although treatment procedures of hunted game differ from slaughtered livestock, the hygienic quality of game meat must still be ensured. Potential indicators of meat hygienic quality include the content of biogenic amines. The aim of the present study was to assess the content and changes of biogenic amines in the muscles of selected kinds of small game (common pheasant and brown hare) during storage, and based on the obtained results, to assess the hygienic quality of the meat. Biogenic amines (putrescine, cadaverine, histamine, tyramine, phenylethylamine, and tryptamine) in the breast and thigh muscles separated by reverse phase liquid chromatography and consequently were detected using tandem mass spectrometry. Based on the determined content of biogenic amines, both pheasant and hare meats complied with values of high quality meat. The sum of biogenic amines did not exceed the value of $5 \mathrm{mg} / \mathrm{kg}$ after 7 days at $0^{\circ} \mathrm{C}$ or $7{ }^{\circ} \mathrm{C}$ in pheasant meat, and after 21 days at $0{ }^{\circ} \mathrm{C}$ or after 14 days at $7{ }^{\circ} \mathrm{C}$ in brown hare meat. The biogenic amine content and the speed of their formation in venison can be very helpful for the evaluation of both meat hygienic quality and safety of these foods during storage.
\end{abstract}

Cadaverine, hygienic quality, putrescine, small game animal, venison

Venison is becoming continually more interesting for consumers in view of its characteristics (low fat content, high protein content, vitamins, micronutrients, and essential fatty acids) (Atanassova et al. 2008; Nuernberg et al. 2011). The treatment of hunted game animals differs considerably from the procedures established for livestock. In particular, the possibility of storing hunted feathered game in its feathers and hunted hare in its skin at home for a relatively long period of time within the traditions of hunting distinguishes game from the meat of livestock animals. Although the procedures for hunted game animals are different, the hygienic quality must still be ensured.

One potential indicator of the hygienic quality of meat is the content of biogenic amines in the meat; their increased concentration of them in foodstuffs is associated with increased microbial contamination and spoilage (Ruiz-Capillas and Jiménez-Colmenero 2004; Naila et al. 2010). In a previously presented work, Hernández-Jover et al. (1996) classified the hygienic quality of meat on the basis of the content of biogenic amines (the sum total of putrescine, cadaverine, tyramine, and histamine) and recommend the following limits: $<5 \mathrm{mg} / \mathrm{kg}$ for meat of high hygienic quality; $5-20 \mathrm{mg} / \mathrm{kg}$ for meat of acceptable quality with initial signs of spoilage; $20-50 \mathrm{mg} / \mathrm{kg}$ for meat of poor quality, and $>50 \mathrm{mg} /$ $\mathrm{kg}$ for spoiled meat. Several previously presented works were focused on biogenic amine content in the meat of farm animals, e.g. Silva and Glória (2002); Tamim and Doerr (2003); Balamatsia et al. (2006) in poultry; and Dadáková et al. (2012) in rabbits. Only a limited number of publications, however, focus on monitoring the biogenic amine 
content in the meat of small game animals, e.g. monitoring changes in the concentrations of biogenic amines in connection with the development of contaminating micro-organisms in hunted pheasant stored untreated for 14 days after hunting (Paulsen et al. 2008b); the quantity of biogenic amines in the muscle tissue of small game (feathered pheasants) (Hutařová et al. 2013a; 2013b; 2013c); and the presence of biogenic amines in the muscle tissue of hunted ducks (Hutařová et al. 2014). Biogenic amine content in the internal organs of hares was presented by Paulsen et al. (2008a). However, no significant data on the content of biogenic amines in the muscle tissue of hares has been published to date. Our work focuses on the content of biogenic amines in the muscles of the hunted pheasant and hare stored untreated after hunting (without evisceration). The aim of the study was to determine the content of biogenic amines in the meat of small game animals stored with their feathers or skin still attached for a period of 21 days at $0{ }^{\circ} \mathrm{C}$ or $7{ }^{\circ} \mathrm{C}$ with the intention of determining the period for which the game can be stored while maintaining a content of biogenic amines corresponding to the high quality or acceptable quality of the game.

\section{Materials and Methods}

Hunted pheasants and hares were obtained from small-game hunting during the autumn and winter of 2012. For the purposes of this study only carcasses of hunted game animals primarily appointed for sale were used (this fact maintained minimal muscle lesions deriving from lead pellets). A total of 40 pheasants and 12 hares were used for the research purposes. After hunting, the pheasants in their feathers and hares in their skin were hung without evisceration in the storage space at a pre-set temperature of $0{ }^{\circ} \mathrm{C}(20$ pheasants and 6 hares $)$, and $7{ }^{\circ} \mathrm{C}$ (20 pheasants and 6 hares), and stored for 21 days. The use of the temperature of $0{ }^{\circ} \mathrm{C}$ was based on the storage temperature stipulated for the storage of food of animal origin by the EC Regulation 853/2004, and the temperature of $7{ }^{\circ} \mathrm{C}$ was based on Czech national legislation (Act No. 166/1999 Coll., on veterinary care and on the change of some related laws, and Decree No. 289/2007 Coll., on veterinary and hygiene requirements which are not regulated by directly applicable Community legislation) that allows a different storage regime for this game in compliance with the EU legislation. On day 1, and subsequently on days 7, 14 and 21 after animal shooting, samples from an intact part of the muscle from the breast muscle tissue $(10 \times 4)$ and the thigh muscle tissue $(10 \times 4)$ of 10 pheasants were taken. Ten pheasants were used in the first two weeks (right side breast and left side thigh muscles for day 1 , and conversely for day 7). The same procedure was employed for the next 10 stored pheasants on days 14 and 21. Similarly, samples from 6 brown hares, from the shoulder muscle $(6 \times 4)$ and the hind leg muscle $(6 \times 4)$ were taken.

Biogenic amines were separated by reverse phase liquid chromatography and consequently detected by tandem mass spectrometry. The total amount of $0.5 \mathrm{~g}$ of homogenised muscle tissue from each animal was used. Samples were employed by one-step extraction using 5\% mixture of trichloracetic acid in water followed by a cleanup step using a $0.45 \mu \mathrm{m}$ syringe filter. Biogenic amines were separated from extract by reverse phase liquid chromatography using $\mathrm{C}_{18}$ column $(2.1 \mathrm{~mm} \times 50 \mathrm{~mm}, 1.9 \mu \mathrm{m}$; Thermo, San Jose, CA, USA $)$ and detected by tandem mass spectrometry using a heated electro spray-ionization in a positive ion mode. Thermo Scientific UHPLC Accela 1250 system was connected to a Thermo Scientific TSQ Quantum Access MAX Triple Quadrupole Instrument (Thermo, San Jose, CA, USA). The method used for the purposes of this study was carried out according to the previously presented method (Hutařová et al. 2013c). The biogenic amines putrescine, cadaverine, tyramine, histamine, tryptamine, and phenylethylamine were determined in the samples of breast/ shoulder muscles and thigh/hind leg muscles of selected small game animals. Contrary to the previously described evaluation of hygienic quality of meat (Hernández-Jover et al. 1996) based on the content of four biogenic amines (putrescine, cadaverine, tyramine, and histamine), we used also phenylethylamine and tryptamine, the presence of which in elevated content used to be also connected with meat spoilage. Their content in the analysed samples was found in levels comparable to histamine.

The content of biogenic amines was calculated for each sample as the sum of the content of putrescine, cadaverine, tyramine, histamine, tryptamine, and phenylethylamine. Results were analyzed using the statistical package Unistat 5.6. For all variables tested, normality was checked using Shapiro-Wilk test. Because of their heterogeneous variances, data were subjected to Kruskal-Wallis ANOVA and subsequently to non-parametric Tukey-type multiple comparison tests with ranked sums in order to assess the differences between all possible pairs of groups. A level of $P<0.05$ was considered significant.

\section{Results}

We determined the content of biogenic amines in the breast and thigh muscle of hunted common pheasants during storage with the feathers still attached over a period of 21 days. The results for the storage temperatures of $0^{\circ} \mathrm{C}$ and $7{ }^{\circ} \mathrm{C}$ are shown in Figs 1 and 2, respectively. 


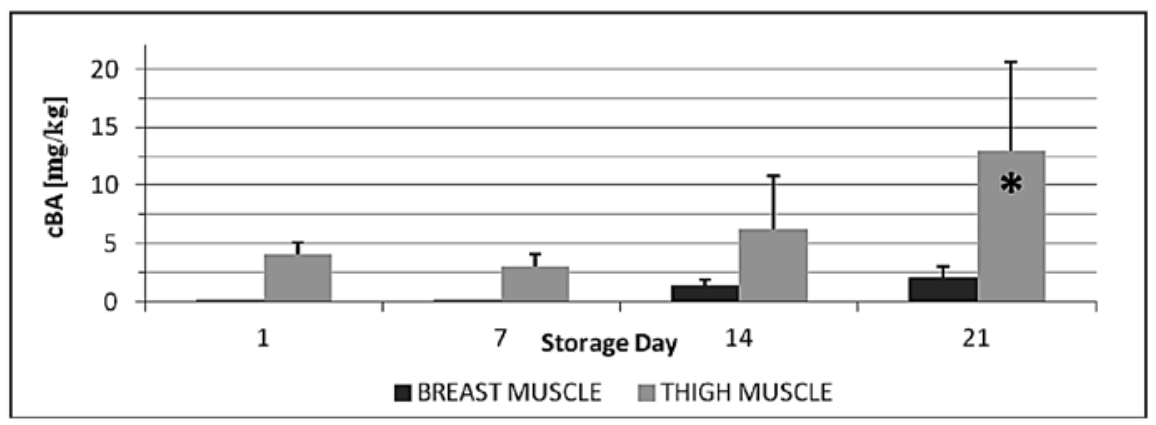

Fig. 1. Biogenic amine content (cBA) in the breast and thigh muscles of pheasants stored untreated at $0{ }^{\circ} \mathrm{C}$.

*Significant difference compared with the value of $5 \mathrm{mg} / \mathrm{kg}$

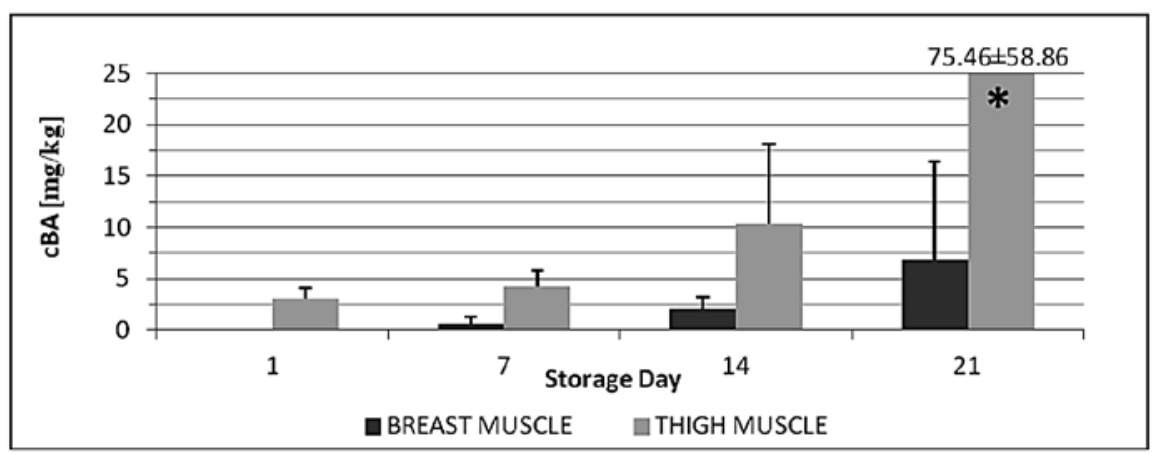

Fig. 2. Biogenic amine content (cBA) in the breast and thigh muscles of pheasants stored untreated at $7{ }^{\circ} \mathrm{C}$.

*Significant difference compared with the values of 5 and $20 \mathrm{mg} / \mathrm{kg}$

The influence of storage temperature on the biogenic amine content was considered by comparing pheasant muscles stored at $0{ }^{\circ} \mathrm{C}$ and $7{ }^{\circ} \mathrm{C}$. A higher content of biogenic amines was observed in muscles of pheasants stored at $7{ }^{\circ} \mathrm{C}$ compared to $0{ }^{\circ} \mathrm{C}$. Significant difference in the total content of biogenic amines between $0{ }^{\circ} \mathrm{C}$ and $7{ }^{\circ} \mathrm{C}$ was not detected for breast muscles, whereas the difference was observed in thigh muscles on day 21 $(P<0.05)$.

Furthermore, differences in the content of biogenic amines in breast muscle of pheasants compared to thigh muscles were assessed. Significant differences in the content of biogenic amines both at $0{ }^{\circ} \mathrm{C}$ and $7{ }^{\circ} \mathrm{C}$ between the breast and thigh muscles were found on days 1 , 7,14 , and $21(P<0.05)$, with the higher content of biogenic amines in the thigh muscle compared to the breast muscle.

Comparison of biogenic amine content in the muscle of brown hares with the value of 5 $\mathrm{mg} / \mathrm{kg}$ (representing the value of meat of high hygienic quality) and the value of $20 \mathrm{mg} / \mathrm{kg}$ (representing the value of meat of acceptable quality) for storage temperature of $0{ }^{\circ} \mathrm{C}$ and $7{ }^{\circ} \mathrm{C}$ is shown in Fig. 3 and Fig. 4, respectively.

The difference in the biogenic amine content in the muscle of hares, stored at $0{ }^{\circ} \mathrm{C}$ and 


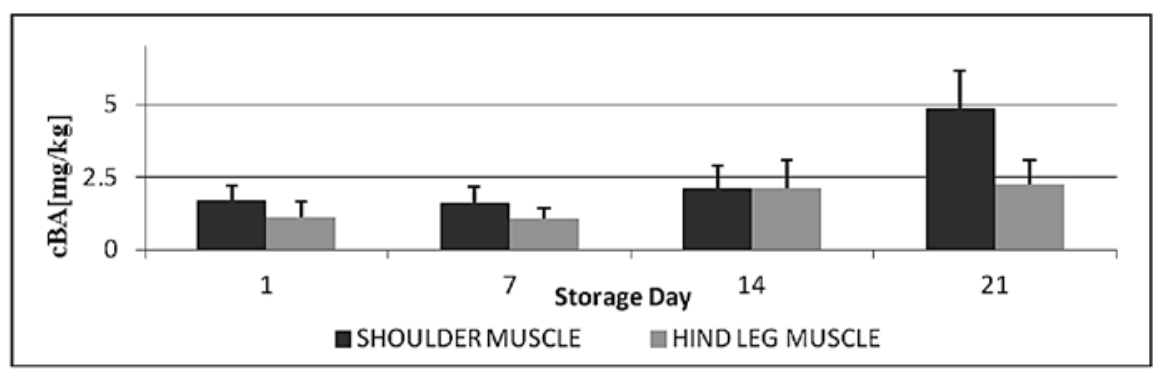

Fig. 3. Biogenic amine content (cBA) in shoulder muscle and hind leg muscle of hares stored untreated in the skin at $0{ }^{\circ} \mathrm{C}$.

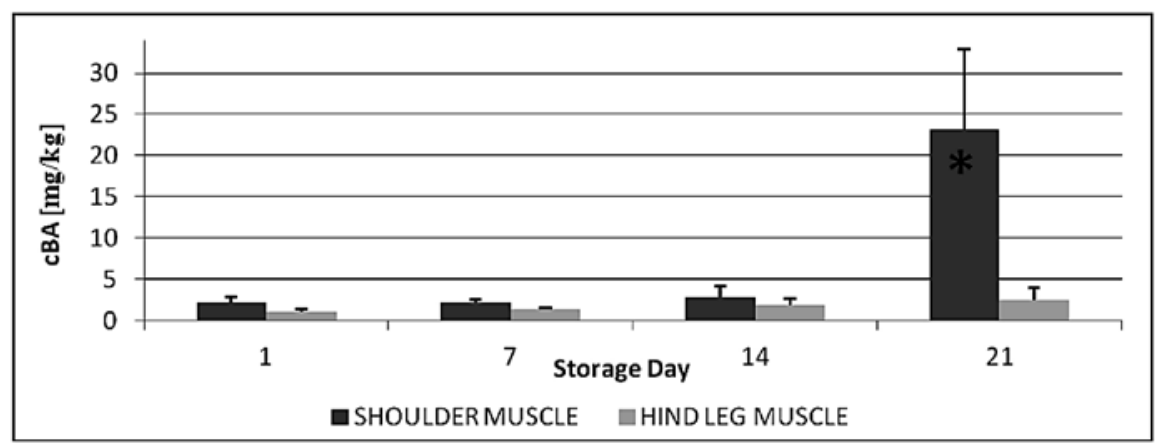

Fig. 4. Biogenic amine content (cBA) in shoulder muscle and hind leg muscle of hares stored untreated in the skin at $7^{\circ} \mathrm{C}$.

*Significant difference compared with the value of $5 \mathrm{mg} / \mathrm{kg}$

$7{ }^{\circ} \mathrm{C}$ was determined. As expected, the results show a higher content of biogenic amines at the storage temperature of $7{ }^{\circ} \mathrm{C}$ compared to $0{ }^{\circ} \mathrm{C}$. A significant difference $(P<0.05)$ in the content of total biogenic amines at $0{ }^{\circ} \mathrm{C}$ compared to $7^{\circ} \mathrm{C}$ was found for shoulder muscles on day 21 . No significant differences of biogenic amine contents were found in the hind leg muscles.

Finally the difference in the biogenic amine content in muscles of hind legs and shoulders was assessed. A significant difference $(P<0.05)$ in the content of biogenic amines was found at $0{ }^{\circ} \mathrm{C}$ between the hind leg and shoulder muscles on day 21 , and at storage temperature of $7{ }^{\circ} \mathrm{C}$ between the hind leg and shoulder muscles on days 1,7 , and 21 . A higher content of biogenic amines was assessed in the shoulder muscles compared to hind leg muscles.

\section{Discussion}

By determination of biogenic amines in the meat of common pheasants hunted with shotgun, we found that the content of biogenic amines in the breast and thigh muscle corresponds to the values for meat of high quality for the period of 14 days at $0{ }^{\circ} \mathrm{C}$ and $7{ }^{\circ} \mathrm{C}$. On day 21 , the biogenic amine content in the breast muscle corresponded to values for meat of high quality at $0{ }^{\circ} \mathrm{C}$ and $7{ }^{\circ} \mathrm{C}$. At the end of the storage period, the thigh muscle could be classified as meat of acceptable quality at $0{ }^{\circ} \mathrm{C}$, and as spoiled meat at $7{ }^{\circ} \mathrm{C}$. At 
both storage temperatures $\left(0\right.$ and $\left.7^{\circ} \mathrm{C}\right)$ higher values of biogenic amines were found in the thigh muscle compared to the breast muscle.

These results are consistent with the findings stated in the work considering differences in the increase in the content of biogenic amines in the muscle tissue of hunted pheasants stored at temperatures of 0 and $4{ }^{\circ} \mathrm{C}$ (Paulsen et al. 2008b). The highest biogenic amine content in their study was found for tyramine, histamine, and putrescine. According to the results obtained in our study, the biogenic amines of the greatest value as indicators can be considered putrescine, cadaverine and tyramine, whose content attained the highest values in the muscle tissue of pheasants. The changes in the content of these biogenic amines were also the most pronounced during storage.

The results of studies focused on changes in the biogenic amine content in the muscle tissue of pheasants killed by pithing and left with their feathers still attached during storage (Hutařová et al. 2013a; 2013b; 2013c), have shown that the muscles of pithed pheasants corresponded to meat of high hygienic quality over the storage period of 21 days at both $0{ }^{\circ} \mathrm{C}$ and $7{ }^{\circ} \mathrm{C}$ (the value of $5 \mathrm{mg} / \mathrm{kg}$ was not exceeded at any time during the storage period). In accordance with the present study, a higher content of biogenic amines was also found in the thigh muscles compared with the breast muscles both in hunted and pithed pheasants. The difference was only found on storage day 21 , when the content of biogenic amines in the thigh muscle of hunted pheasants was higher than $5 \mathrm{mg} / \mathrm{kg}$ (i.e. higher compared with biogenic amines determined in muscles of pithed pheasants).

In the work concerning the content of biogenic amines in the muscle of hunted ducks (Hutařová et al. 2014), a higher content of biogenic amines was found, as well as a higher speed of formation (a value of $5 \mathrm{mg} / \mathrm{kg}$ was exceeded in the muscle of ducks after only 7 days of storage) compared to the hunted pheasants assessed in our study. A higher content of biogenic amines was reported in the thigh muscle of hunted ducks compared to the breast muscle tissue. Similarly, a higher biogenic amine content was found in the thigh muscle compared to the breast muscle of hunted pheasants in the present study.

The biogenic amine content determined in hind leg and shoulder muscles of hunted hares corresponded to the values for meat of high quality for 14 days at $0{ }^{\circ} \mathrm{C}$ and $7{ }^{\circ} \mathrm{C}$. The content of biogenic amines on day 21 in the muscles of the hind leg corresponded to values for meat of high quality at $0{ }^{\circ} \mathrm{C}$ and $7{ }^{\circ} \mathrm{C}$, and in shoulder muscle to values for meat of high quality at $0{ }^{\circ} \mathrm{C}$, and of acceptable quality at $7^{\circ} \mathrm{C}$. Higher values of biogenic amines were found in the shoulder muscle compared to those in muscle of hind leg at both storage temperatures.

Comparing the content of biogenic amines in the meat of the common pheasant and the brown hare, we found that values corresponding to meat of high quality persist in the brown hare for longer time than in the common pheasant. Comparison of the results obtained in our study with the results available for other species of small game (Paulsen et al. 2008b; Hutařová et al. 2013a; 2013b; 2013c for pheasants; and Hutařová et al. 2014 for hunted ducks) obtained in studies conducted under comparable conditions (carcasses of killed game stored without removal of the digestive tract) clearly show that, from the viewpoint of biogenic amines, pithed pheasant can be said to be the meat that remains fresh for the longest time, followed by the hare and hunted pheasant; the meat that remains fresh for the shortest period is hunted duck.

Based on the results of the content of biogenic amines in the meat of hunted common pheasants, it can be recommended to be stored in feathers for 14 days at both $0{ }^{\circ} \mathrm{C}$ and $7{ }^{\circ} \mathrm{C}$ to maintain meat of high quality. After this period, the meat of the thigh muscle can be expected to show values corresponding to meat of acceptable quality at $0{ }^{\circ} \mathrm{C}$, and to spoiled meat at $7{ }^{\circ} \mathrm{C}$.

In terms of the biogenic amine content, the brown hare can be recommended to be stored in its skin for 21 days at $0{ }^{\circ} \mathrm{C}$ to maintain meat of high quality. At $7{ }^{\circ} \mathrm{C}$, values 
corresponding to meat of acceptable quality can be expected in the meat of the shoulder after 14 days of storage.

\section{Acknowledgements}

This study was supported by the project IGA of the University of Veterinary and Pharmaceutical Science Brno 13/2013/FVHE.

\section{References}

Atanassova V, Apelt J, Reich F, Klein G 2008: Microbiological quality of freshly shot game in Germany. Meat Sci 78: 414-419

Balamatsia CC, Paleologos EK, Kontominas MG, Sayvaidis IN 2006: Correlation between microbial flora, sensory changes and biogenic amines formation in fresh chicken meat stored aerobically or under modified atmosphere packing at $4{ }^{\circ} \mathrm{C}$ : possible role of biogenic amines as spoilage indicators. A Van Leeuw J Microb 89: $9-17$

Czech Republic 1999: Act No. 166/1999 Coll. on veterinary care on change of some related laws (Veterinary act). In: Collection of Laws of the Czech Republic. Czech Republic 166: 57

Czech Republic 2007: Decree No. 289/2007 Coll. on veterinary and hygiene requirements which are not regulated by directly applicable Community legislation. In: Collection of Laws of the Czech Republic 289: 95

Dadáková E, Pelikánová T, Kalač P 2012: Concentration of biologically active polyamines in rabbit meat, liver, kidney after slaughter and their changes during meat storage and cooking. Meat Sci 90: 796-800

European Commision 2004: Regulation (EC) No. 853/2004 of the European Parliament and of the Council of 29 April 2004 laying down specific hygiene rules for food of animal origin. Off J Eur Union L139:55

Hernández-Jover T, Izquierdo-Pulido M, Veciana-Nogués MT, Vidal-Carou MC 1996: Biogenic amine sources in cooked cured shoulder pork. J Agric Food Chem 44: 3097-3101

Hutařová Z, Forejtek P, Večerek V, Steinhauserová I, Maršálek P, Bořilová G 2014: The effect of treating method of game on the content of biogenic amines in wild duck (Anas platyrhynchos) meat during the course of storage. Eur J Wildlife Res 60: 259-264

Hutařová Z, Večerek V, Maršálek P, Steinhauserová I, Bořilová G 2013a: Changes in biogenic amine concentrations in meat of eviscerated pheasants (Phasianus colchicus) during storage at $7^{\circ} \mathrm{C}$. Acta Vet Brno 82: 175-180

Hutařová Z, Večerek V, Steinhauserová I, Maršálek P, Bořilová G 2013b: Effects of storage temperature on biogenic amine concentrations in meat of uneviscerated pheasants (Phasianus colchicus). ActaVet Brno 82: 61-65

Hutařová Z, Večerek V, Steinhauserová I, Maršálek P, Bořilová G, Forejtek P 2013c: The effect of treating method of pithed pheasant on the content of biogenic amines in the meat during the course of storage. Poultry Sci 92: 2182-2187

Naila A, Flint S, Fletcher G, Bremer P, Meerdink G 2010: Control of biogenic amines in food-existing and emerging approaches. J Food Sci 75: 139-150

Nuernberg K, Slamecka J, Mojto J, Gasparik J, Nuernberg G 2011: Muscle fat composition of pheasant (Phasianus colchicus), wild ducks (Anas platyrhynchos) and black coots (Fulica atra). Eur J Wildlife Res 57: 795-803

Paulsen P, Dičáková Z, Bauer F 2008a: Biogenic amines and polyamines in liver, kidney and spleen of roe deer and European brown hare. Eur Food Res Technol 227: 209-213

Paulsen P, Nagy J, Popelka P, Ledecký V, Marcinčák S, Pipová M, Smulders FJM, Hofbauer, P, Lazar P, Dičáková Z 2008b: Influence of storage conditions and shotshell wounding on the hygienic condition of hunted, uneviscerated pheasant (Phasianus colchicus). Poutry Sci 87: 191-195

Ruiz-Capillas C, Jiménez-Colmenero F 2004: Biogenic amines in meat and meat products. Crit Rev Food Sci Nutr 44: 489-499

Silva CMG, Glória BA 2002: Bioactive amines in chicken breast and thigh after slaughter and during storage at $4 \pm 1{ }^{\circ} \mathrm{C}$ and chicken-based meat products. Food Chem 78: 241-248

Tamim NM, Doerr JA 2003: Effect of putrefaction of poultry carcasses prior to rendering on biogenic amine production. Poultry Sci 12: 456-460 